\title{
Desire Theme in the Movie Lolita
}

\section{He Yizhou}

\author{
XinYu University, Jiangxi Province, City of Xinyu, 338004
}

Keywords: Lolita; Vladimir Nabokov; desire theme; intellectuals; Mental anxiety

\begin{abstract}
The Movie Lolita (1953) is a desire film which is adapted from the contemporary American writer Vladimir Nabokov 's (1899-1977) namesake novel. The novel tells a story of a European immigrant intellectual Humbert's deformed love to Lolita,a sexy girl of fourteen years old. Since its release, the movie caused a stir in the world with mixed reviews of both positive and negative viewpoints. Based on Sigmund Freud, Karl J.Jung, Jacques Lacan, Gilles Deleuze's desire theory, this article analyzed the desire theme in the novel, gave an anatomy of the anxiety and confusion of the modern intellectual , and revealed the implicit sociological topic in the novel.
\end{abstract}

\section{Introduction}

The movie Lolita (1953), with a Chinese translation A Pear Tree Press Begonia, is a desire film adapted from American Russian writer Vladimir Nabokov's (1899-1977) novel written in 1953. Lolita refers to those young girls aged from 9 to 14, with clean, transparent and young body filled with fatal attraction as fairy, not yet mature but sending out the natural luster of the skin, no fortification way of action, cuddly but daring not touch at the same time. Now Lolita has become not only a trademark of many products but also a kind of cultural symbol. Lolita is synonymous with "young sexy but erratic". Also people compared Lolita to "Pandora's box" and man's bane. The movie Lolita describes a period of incredible love between a middle-aged man named Humbert Humbert who emigrated to the U.S. from France in childhood and a 14-year-old girl Anna Belle. Unfortunately, at last Anna Belle died of typhoid fever in her early years, resulting in Humbert's pedophile (The child I love). Since then, he defines "goblin" as "nine to fourteen years old girls". Later, Humbert was first abandoned by a wealthy widow, then had a crush on the landlady Charlotte Haze's 12-year-old daughter Lolita (Lolita), call her as the goblins. Because of emotional shadows in his childhood, Humbert fell in love with Lolita in such a way that he was unable to extricate himself. In order to get close to the precocious little girl, Humbert married the landlady who was Lolita's mother without hesitation, acting as Lolita's stepfather perfect justifiably. The girl in the novel, formerly known as Dolores Haze, with Spanish pronunciation of Lolita or Lo, so the used it as the title. As the novel presented a clear-cut lopsided love story, it was banned in many countries when it came out in 1953. Many critics argue that Lolita is no different from pornography. But British writer Graham Greene's view is different from others, he viewed the book as one of the best novels in 1955, which make this work regain the opportunity to become a sensation all over the world of American movies. The original novel was published in the U.S. in 1958, jumping all the way to the first of the New York times bestseller list.In 1995, the novel won "milestone" in contemporary literature of the New York public library "books of the century". In 1962 and 1997, the novel was adapted into films twice. The first time was in 1962, when the famous Hollywood director Stanley Kubrick adapted it into film and showed it on the screen. The second time wa in in 1997, when another director Adrian Lyne made it into a color film. The film won the 35th annual Academy Awards for best adapted screenplay (nominated), these glories are enough to prove that 
the artistic charm of the film and artistic value of the original works. The film attracted the attention home and abroad with comments full of praise and criticism.But few critics paid attention to the desire theme and modern intellectuals' spiritual anxiety in this novel. This paper analyzed the desire theme, the artistic value and social significance of this film, in attempt to enrich people's understanding of the film and enlighten people's attitudes to desire and love.

\section{Synopsis to the Western Desire Theory}

Desire Theory derives from Austrian pathologist and psychologist Samuel Freud who put forward the notion of libido which he thinks is the source of human power and the release of libido means the satisfaction of desire. And he also put forward the three- layer personality theory: ego, id and super ego. Furthermore, he divided man's psychology into unconsciousness, subconsciousness and consciousness. Desire is the release and representation of ego and unconsciousness. Desire is the release and reflect of id and the unconsciousness. Yet another psychologist, Freud's student, (C.G. Jung,, 1875-1961), showed dissatisfaction with Freud's too much emphasis on sexual motivation. Carl Jung believes that the nature of libido is not as Freud's thought that is caused by sexual excitement and pent up aggressive personality driving force. On the contrary, the libido is the common biological energy of life. Carl Jung put forward the concept of "collective unconsciousness" through the method of prototype analysis. That is, much of human unconscious is the performance of human collective unconscious. Jacques Lacan, a famous French psychoanalyst (Jacques Lacan, 1901-1980) has a clearer view of the theory of desire, he thought that Desire" was the concept of "needs", Because "need" is always the need for a particular object. "Desire" is associated with scarcity, that is, desire is the impulse to go beyond the level of need. Desire can only be produced in the relationship of others, and the desire of the subject is the desire of others, so that the desire of symbolic meaning becomes the motive force of the formation of the subject and the individual and the social development.(Yuechuang,Wang,62) As Lacan (1977) said, "the desire has the strength of interference and vibration." (Lacan, 68) However, Gilles Deleuze (1925-1995) and Felix Guattari (1930-1992) denied Lacan's theory that desire is the lack of demand. They put forward the theory of "desire to produce", the desire to create the reality, the world of human existence, like any production. At the same time, the production of desire produces a deep connection between the individual and the nature and society, and the "desire to produce" creates the individual himself. Man becomes the subject of desire, and obtains the freedom to the external environment and the inherent nature. (Wang Yuechuan, 67) Although these theorists have different opinions on the theory of desire, they agree that literature and art are the release and expression of human desire. In Freud's view, art is the sublimation of original desire, The work of art is nothing but an illusion created by an artist under the domination of the original, This realm of fantasy is writers' refuge, it is set up because people have to give up some instinct in life, suffering from hedonism to realism. (Wang Yuechuan, 30) Like Freud, on the issue of the power of art creation, Carl Jung held the view that the unconsciousness is regarded as the driving force of artistic creation. The power of artistic creation comes from the "independent complex" in the unconsciousness. This kind of activity "ruthlessly enslaved artists to complete their works, even at the expense of their health and the happiness of ordinary people". (C.G.Jung, 1979,75) Lacan introduced linguistics into psychological analysis, he put the "signifier" as the consciousness of language, while the "signified" unconscious process. And he asserts that the unconsciousness manipulates the language representation of the subject, and manipulates it by moving round "I think". When the language and desire doesn't cooperate, unconscious will emerge. Deleuze encouraged artists to break the control of modern society and create a new order which is different from the existing order, to show the 
spirit of the fracture and discontinuity. It is precisely because of the inconsistency between the modern art world and the real world, which reveals the absurd nature of the real world; In modern society, the integrity of the individual is denied by the false collective integrity, the individual denies the integrity of the society with self broken and collective spirit, and reveal the essence and social fragmentation of group psychology." (Wang Yuechuan, 68-69)

\section{The theme of desire in the film "Lolita"}

The film "Lolita" is the presentation of Henbert's memory and recall who is the male protagonist of this film. There is no sexual exposure in the film, the story is also a very common one. Henbert, a professor at the University where he teaches French, due to the tragic death of the first lover, has a different kind, and even can be said to be sick of infatuation to an underage girl. It is because of this fascination that when he saw in the unconscious Sherlock, the daughter of the landlady, at the first sight, he was deeply infatuated with the young girl who was lying on the grass in the garden, enjoying the pictures of the girls. In the bright sunlight, under the lawn sprinkler water, the young girl in wet shirt, looks so beautiful and appears a charming face. It is this beautiful picture that defeats Henbert, so that he can not extricate themselves. And the professor at the University of the refined and cultured also conquered Lolita's widowed mother Sherlock. Three people fall into a twisted relationship net. In order to get close to the hearts of the goblins, Henbert did not hesitate to live down. In their daily life, Lolita's lovely, youthful, character and her sometimes love for Henbert and sometimes ignorance to Henbert make Henbert more obsessed and inextricably bogged down in. In order to maintain a good relationship with Lolita, he even accepted her mother as his wife. Unfortunately, his diary was found by Sherlock, along with the exposure of his conspiracy of close to Lolita. Poor Sherlock ran out of the yard and died under the wheels. Henbert took the chance and returned to Lolita who is in the summer camp, and began a journey of incest with her. On the way, they finally had a sexual relationship. Until Lolita became bored with the relationship between them, and secretly left with Kwedi (a disabled, perverted writer). But Henbert did not give up, he had searched her for three years, but found that she has been through the vicissitudes of life, married a young man and with children. In despair, he killed Kwedi who cajoled Lolita, he himself was arrested and imprisoned. And Lolita died of childbirth. The four main characters are all dead, the film ends with a lament tragedy. The film is a true but somewhat bizarre story of desire. The hero of the film can not get out of the shadow of the affair where his first love died young and fell into the absence of desire. He could not find his first love in real life, and fell into a kind of fictitious desire. Although Sherlock, the landlady, loved Humbert, he had no intention. As the landlord's daughter brought back his first love, he was desperate to pursue his lost first love, to meet their own desires. From the initial approach, viewing, to the ultimate desire to implement the plan. Henbert has been caught in a morbid desire to pursue. However, Lolita is not really in love with the professor, when she and another man left Henbert, he was in a relentless pain, and he used retaliatory means to kill their ideal lover's rival, and he himself was thrown in jail and eventually died of desire. $t$ is no wonder that after the film was released, it caused a deep ethical dispute. Because after all, Lolita is still a minor, and Henbert is a knowledgeable University professors with moral cultivation. However, if analyzed from Freud's theory of sexual instinct, we can easily find that desire is a human instinct, the pursuit of desire, to meet the desire is the instinct of life. The lack of desire will inevitably lead to the imbalance of personality and psychological deformity. According to Deleuze's desire theory of production, Henbert has opened the human desire machine, with non-stop wheels. There are such comments as this is a sinful life, a beautiful dream, a restless desire, an arrogant dream, a heart wrenching misery. The author believes that this is a tragedy of desire, reflecting the 
spirit of modern intellectuals and the plight of survival. At the same time, the film has a profound contemporary sociological value. In today's materialistic society, the expansion of people's desire means indulging unrestrained desire, which will be caught in the crossroads, excessive suppression of desire, will produce distorted mind and psychological metamorphosis. In the present society with materialism and consumerism in trend, rational control of each person's desire is very necessary. Because indulging the desire will give themselves and others suffering and tragedy; But at the same time, blindly suppressing desire tends to produce psychological deformity, emotional distortion, the suppression of personality. I think we should all have a rational view of the economic and social development pressure, rationally treat the temptation from life, network space and in real life, the reasonable control of their own desires, rationally pursue their own desires, let the desire become the promotion of social progress, and promote the healthy development of the power of human nature, make reasonable noble the desire to become the collective unconscious, motive and positive energy pursuit of national rejuvenation and human progress.

\section{Conclusion}

Although "Lolita" is a masterpiece of the 1950s in the west, but its sociological value has gone beyond the limitations of time and space. Desire is the pursuit of everyone's heart. As we all know, if there is no desire, there is no motivation. But man is a rational animal, and desire must be carried out on the basis of ethics. The pursuit of desire in the movie "Lolita" is full of tragic beauty, and it also causes people to think deeply. As one of the higher intellectuals in the $20^{\text {th }}$ century, the lack of desire lead people to reflect, this lack of desire symbolize the spiritual confusion and dilemma of the modern intellectuals, under the glamorous appearance, there actually hides a broken heart. Lolita reveals the spiritual anxiety of modern people. Literature is the release of the inner thoughts of the author, and the novel reflects the inner anguish experience of Nabokov during his exile in Europe. At the same time, the novel gives us a profound enlightenment to contemporary people, the pursuit of desire should be in the ethical constraints, otherwise it will be subject to legal and spiritual condemnation, therefore, this movie also has rich social value, it always reminds us that man is a rational animal, and we should follow the ethical pursuit of desire go hand in hand. Let the reasonable noble desire to become a collective unconscious, the pursuit of national rejuvenation and human progress of the driving force and positive energy.

\section{About authors}

He Yizhou, male, born in 1970, master of Hunan, Born in Hengyang, associate professor of Xinyu University, mainly engaged in foreign literature, foreign language teaching and research.

\section{Reference}

[1] Wang Yuechuan. Contemporary western literary theory tutorial [M]. Shanghai: Fudan University press, 2008

[2] Jacques, Lacan. The Fundaamental of trans. By Alaan Sheridan, London, 1977, Four, Concepts, Psychoanalysis[M].

[3] C.G.Jung. Collected of Princeton University Press, 1979, Vol.15., Works, C.G.Jung[M]. 